\title{
SMALLPOX IN SEVENTEENTH-CENTURY ENGLISH \\ LITERATURE: REALITY AND THE METAMORPHOSIS OF WIT
}

\author{
by
}

\author{
RAYMOND A. ANSELMENT*
}

When smallpox claimed the only son of the sixth Earl of Huntingdon on 24 June 1649 , the death of Henry, Lord Hastings was commemorated in a fashionable volume of elegies. Among the contributions to Lachrymae musarum by "diverse persons of Nobility and Worth", Andrew Marvell's tribute to the young Huntingdon heir is certainly the most intriguing and those of John Denham and Robert Herrick rank with the most polished, but none has gained the notoriety of the poem written by John Dryden. This studied, uneven imitation of classical and metaphysical elegy has often been singled out for its infamous description of the fatal disease:

\author{
Blisters with pride swell'd; which th'row 's flesh did sprout \\ Like Rose-buds, stuck i' th' Lily-skin about. \\ Each little Pimple had a Tear in it, \\ To wail the fault its rising did commit: \\ Who, Rebel-like, with their own Lord at strife, \\ Thus made an Insurrection 'gainst his Life. ${ }^{1}$
}

Despite attempts to dismiss the "gross", "forced and far-sought conceits" as the unpropitious performance of a fledgling, eighteen-year-old poet or to justify their wit as rhetorically appropriate figures of speech, ${ }^{2}$ the lines remain an affront to most sensibilities. The passage, nevertheless, should not be dismissed as simply an aberration of seventeenth-century wit or a juvenile lapse in good taste. Though the poem appears flawed, particularly in comparison with Dryden's later accomplishments, the failure of this occasional poem provides the occasion for a better understanding of both the medical and the literary history of smallpox in the seventeenth century.

\footnotetext{
${ }^{*}$ Raymond A. Anselment, PhD., Department of English, University of Connecticut, Storrs, CN 06268, USA.

' John Dryden, 'Upon the death of the Lord Hastings', in The works of John Dryden, ed. Edward Niles Hooker and H. T. Swedenberg, Jr., Berkeley and Los Angeles, University of California Press, 1956, vol. 1, p. 4. Hereafter cited in the text.

${ }^{2}$ The miscellaneous works of John Dryden, London, 1760, vol. 1, p. iii; and The poetical works of John Dryden, London, 1811, vol. 1, p. 2. Gayle Wilson summarized some of the modern criticism in his attempt to justify the poem rhetorically, 'Genre and rhetoric in Dryden's "Upon the death of Lord Hastings", Southern Speech Journal, 1970, 35: 256-66.
} 
The death of an undistinguished nineteen-year-old lord on the eve of his marriage and the response of a then equally undistinguished poet, it must be admitted at the outset, run some risk of being lost in the commonplace. The aristocracy contributed its share to the high mortality rates of the period, and the passing of lords as well as commoners occasioned an increasing number of largely mediocre elegies. Certainly the historical and literary significance of the Huntingdon family tragedy pales in relation to the deaths of Prince Henry, Elizabeth Drury, and Edward King; other contemporaries, for that matter, had also suffered the deaths of an heir apparent and mourned their fates with similar poetic commissions. The circumstances surrounding the loss of Lord Hastings, however, add poignancy and irony to the grief. The Earl of Huntingdon had hoped to recoup the family's dwindling fortunes through his son's marriage to Elizabeth Mayerne, the daughter of a prominent royal physician, and Hastings's death the day before the wedding was a double blow to both the Earl and his wife. ${ }^{3}$ Their frustration was compounded by their futile efforts to save the young lord: Elizabeth's distinguished father cared for his future son-in-law throughout the sickness, but the physician who had written about the cure of smallpox "in vain strove to apply/Med'cines" (p. 5). Mayerne's obvious failure to arrest the disease and Dryden's apparent failure to address the loss adequately underscore a reality unique to the seventeenth century. Before this century, smallpox was not a major threat to the English, and after it inoculation offered some relief from the dreaded disease. Without this hope and with only a limited understanding of the sickness, physician and poet alike wrestled with the growing epidemic. The following analysis of their struggle assumes that the literary response cannot be separated from the medical reality. ${ }^{4}$

Along with the scientific treatises and physicians' accounts, diaries, letters, memoirs, and poems provide a rich source of information about the medical history of the seventeenth century. Statistical data gleaned from the incomplete Bills of Mortality indicate that during this period smallpox displaced the plague as the leading cause of death, but the graphs and numbers give no sense of the nightmarish suffering that affected all levels of society. The physical and psychological scars common to rich and poor alike are apparent both in the plight of the afflicted and in the attempts to assuage the horrors of suffering. Among the myriad diseases of the seventeenth century, smallpox in particular seized the poetic imagination, and this essay explores the relationship between the pressing fears of the epidemic and the fanciful, often disconcerting reactions of the poets. In the context of the widespread suffering described in the next section, the poems' perplexing resolutions appear neither tasteless

\footnotetext{
${ }^{3}$ H. T. Swedenberg, Jr. provides the biographical information in the California edition of Dryden and in his essay, 'More tears for Lord Hastings', Huntington Library Quarterly, 1952-53, 16: 43-51.

4 Among Renaissance literary scholars, the "new historicists" have increasingly emphasized the interdependency of literary text and culture, but this study is more sympathetic to the approach of British historians such as Kevin Sharpe, who stress the important role literature plays in illuminating the social and political history of the seventeenth century. The theoretical assumptions and practical applications of this approach are apparent in Lauro Martines, Society and history in English Renaissance verse, Oxford, Basil Blackwell, 1985; Politics of discourse, ed. Kevin Sharpe and Steven N. Zwicker, Berkeley and Los Angeles, University of California Press, 1987; and Kevin Sharpe, Criticism and compliment, Cambridge University Press, 1987.
} 
flights of wit nor outright failures to offer solace; the remainder of the essay suggests that they paradoxically mirror the shared predicament of contemporaries caught between the desire to recoil from the ravages of smallpox and the need to accept the mounting crisis. The strained, often questionable wit of the poets is symptomatic of the graphic realities of the disease; together both illuminate the personal and social impact of a virulent epidemic of major importance in the history of medicine.

Dryden's description of smallpox as a "Foul Disease", "The very Filth'ness of Pandora's Box" (p. 4), reflects considerable historical accuracy despite its poetic licence. Two centuries later the famous English historian Thomas Babington Macaulay would contend that in the seventeenth century smallpox "was then the most terrible of all the ministers of death". In his account of Queen Mary's doomed struggle with the disease, Macaulay insisted that at the time of her death in 1694 smallpox had supplanted the plague as the most dreaded scourge:

The havoc of the plague had been far more rapid: but the plague had visited our shores only once or twice within living memory; and the small pox was always present, filling the churchyards with corpses, tormenting with constant fears all whom it had not yet stricken, leaving on those whose lives it spared the hideous traces of its power, turning the babe into a changeling at which the mother shuddered, and making the eyes and cheeks of the betrothed maiden objects of horror to the lover. ${ }^{5}$

Macaulay's melodramatic account of the epidemic's virulence involves an overstatement suited to the drama of the Queen's crisis and ignores the fact that the mortality rate from the disease continued to increase in the eighteenth century, but the inflated narrative does not negate the accuracy of Macaulay's basic perception. Though medical statistics for this and earlier periods are notoriously difficult to compile, the incomplete Bills of Mortality and selected parish registers confirm the rise of smallpox. Even before the last great outbreak of plague in 1665, the Venetian ambassador observed from London that smallpox "is considered here on a par with the plague", and in the 1670s and 1680s the percentage of deaths from this disease approached the mortality rate of the peak years of the next century. ${ }^{6}$ Contemporary observers knew and experienced the destructiveness of smallpox and its growing threat.

For them the disease appeared as a recent danger of mounting proportion. William Clinch, in An historical essay on the rise and progress of the small-pox, written in 1725, asserted unequivocally that "it is without all Doubt a Disease of some Hundred Years standing, yet is it far from being of that Antiquity, which some have imagin'd." ${ }^{7}$ Writers

\footnotetext{
${ }^{5}$ Thomas Babington Macaulay, The history of England, ed. Charles Harding Firth, London, Macmillan and Co., 1914, vol. 5, p. 2468.

${ }^{6}$ Peter Razzell, The conquest of smallpox, Firle, Sussex, Caliban Books, 1977, pp. 101-39; W. A. Guy, 'Two hundred and fifty years of small pox in London', J. statistical Soc., 1882, 45: 399-437; Calendar of state papers, Venetian, ed. Allen B. Hinds, London, HMSO, 1925, 1640-1642, vol. 25, p. 99. In his study of inoculation and vaccination, The speckled monster, Chelmsford, Essex, Essex Record Office, 1987, J. R. Smith stressed the impact of smallpox on the eighteenth century; see, in particular, pp. 15-29.

${ }^{7}$ William Clinch, An historical essay on the rise and progress of the small-pox, London, 1725, p. 2.
} 
as diverse as the distinguished physician Thomas Sydenham and the opportunistic pamphleteer Marchamont Nedham agreed that "In the dayes of Hippocrates and Galen, the Small-Pox and Measels were either altogether unknown, or else so light and easie, that they were never reckoned as particular diseases." 8 Others tried unsuccessfully to locate smallpox among the afflictions of Job, and many noted the absence of any references to the illness in biblical, Greek, and Roman times. Medela medicinae (1665), in fact, anticipated Charles Creighton's monumental History of epidemics in Britain (1891-4): "And in after-time we hear no such News of them, till the Arabians began to describe the Small Pox as a Disease distinct from others; but then they were very gentle, and thus continued till about 40 . years agoe, and less." ${ }^{\text {"T }}$ Though modern epidemiologists note the presence of smallpox among the peoples of earlier civilizations, recent studies tend to support Creighton's contention that the first clinically documented case of smallpox did not occur in England until the reign of Elizabeth. ${ }^{10}$ When the first English "treatise of the small pockes" appeared in 1593 as an appendix to $A$ defensative against the plague, the presence of the disease was in any case unquestionable. "I neede not greatly to stande vpon the description of this disease," Simon Kellwaye began, "because it is a thing well knowen vnto most people." 11 By the time this treatise was reissued in 1652 the virulence of smallpox was an established reality. The unknown author of The charitable pestmaster (1641) found a current outbreak of smallpox "to bee more malignant, then any that have reigned in my remembrance", and the noted writer and physician Thomas Browne concurred two decades later that "the Small-Pox grows more pernicious". ${ }^{12}$ These impressions are summed up in a treatise by Thomas Sydenham preliminary to his major contribution to the study of smallpox, Observationes medicae. "The Small pox", Sydenham observed in this manuscript dated 1669 , "of all other diseases is the most common, as that which sooner or later (at least in this part of the world) attaques most men."13

Its impact on the seventeenth century was unlike the other more famous pestilence, the plague. The English in the port cities and crowded centres of population had lived for centuries with the feared bubonic plague. Children and young people were particularly vulnerable to the bacillus transmitted by fleas from rodents to humans, and the high mortality rate of sixty to eighty per cent devastated families. Outside the urban areas of congestion "Plague comes seldom, but then very sore", often killing a

\footnotetext{
${ }^{8}$ Marchamont Nedham, Medela medicinae, London, 1665, p. 53. Thomas Sydenham wrote that neither Galen nor Hippocrates mentioned smallpox.

${ }^{9}$ Nedham, op. cit., note 8 above, pp. 53-4.

${ }^{10}$ Charles Creighton, $A$ history of epidemics in Britain, London, 1891-4; reprinted with additional notes, New York, Barnes and Noble Inc., 1965, vol. 1, p. 460. Ann G. Carmichael and Arthur M. Silverstein, 'Smallpox in Europe before the seventeenth century: virulent killer or benign disease?', J. Hist. Med., 1987, 42: 147-68, are the latest scholars to confirm Creighton's view. Donald R. Hopkins's Princes and peasants: smallpox in history, University of Chicago Press, 1983, suggests, however, the earlier and global origins of smallpox.

${ }_{11}$ Simon Kellwaye, A Defensative against the plague, London, 1593, p. 38. His 'A short treatise of the small pockes' was reissued in 1652 as part of $A$ treatise concerning the plague and the pox.

12 The charitable pestmaster, London, 1641, p. 9; Thomas Browne's 'A letter to a friend, upon occasion of the death of his intimate friend', in The works of Sir Thomas Browne, ed. Geoffrey Keynes, University of Chicago Press, 1964, vol. 1, p. 107.

${ }^{13}$ P. 290 of Kenneth Dewhurst's transcription in 'Sydenham's original treatise on smallpox with a preface, and dedication to the Earl of Shaftesbury, by John Locke', Med. Hist., 1959, 3: 278-302.
} 
larger percentage of its victims; and within the cities the disease appeared more selective as well as more frequent. ${ }^{14}$ In The history of the pestilence (1625) George Wither described the frightening and usually short infection as "a Rationall Disease",

$$
\mathrm{w}^{\mathrm{ch}} \text { cann }
$$

Pick $w^{\text {th }}$ discretion here and there a man:

And passe o're those, who either marked are

ffor Mercy, or a greater Plague to beare. ${ }^{15}$

Modern epidemiologists note a pattern that is social and not providential in dimension. Baldly stated, "The plague is a poor man's disease": poverty breeds an environment for rats as well as fleas, and poverty traps its victims in these conditions. ${ }^{16}$ Sophisticated studies demonstrate that within the same urban area plague selectively visited the poor and spared their richer neighbours, presumably because the fortunate had a standard of living that protected them from sources of infection. "No man", a seventeenth-century observer asserted without any trace of irony, "could suspect a lady to die of the plague", 17 and deaths among the gentry and upper classes were disproportionately low. When the hot summer days encouraged the spread of plague, those with houses in the country or the means for lodgings there followed the expedient available to them: they fled from the threat of infection. Official policies of quarantine and the establishment of pesthouses further indicate that the seventeenth century could contain, if not control, a disease that seemed to follow an understandable course during its periodic infestations. The same cannot be said about the increasingly common virus smallpox.

Paradoxically this disease became, in the seventeenth century, both less and more traumatic than the plague. Epidemiologists speculate that the virus may have been often confused with measles or smallpox, and that in England a milder form of the virulent variola major may have been inconspicuously common before the deadlier virus emerged so forcefully in the seventeenth century. An upper respiratory disease that characteristically produced skin eruptions about twelve days after incubation began, the more serious form of smallpox killed its victims by attacking the internal organs. The mortality rate, however, was not as severe as the plague; modern studies indicate a fatality rate of between fifteen and forty per cent for the most deadly variola major and between sixty and eighty per cent for the common plague bacillus. ${ }^{18}$ Because

\footnotetext{
14 From Letters and papers of Henry VIII, XIII (i), 1538, p. 14, as quoted by Paul Slack, The impact of plague in Tudor and Stuart England, London, Routledge \& Kegan Paul, 1985, p. 64. Charles Creighton's book (op. cit., note 10 above) also has a long discussion of the plague, but Slack has offered the most important analysis of the plague in the sixteenth and seventeenth centuries. He did not write about smallpox, but his argument about the social dimensions of the plague influenced the following observations about the social implications of smallpox.

${ }^{15}$ George Wither, The history of the pestilence (1625), ed. J. Milton French, Cambridge, MA, Harvard University Press, 1932, p. 65.

${ }^{16}$ F. P. Wilson, The plague in Shakespeare's London, Oxford University Press, 1927, p. 172. Paul Slack's recent study (see note 14 above) has documented the disease's social bias.

${ }^{17}$ Sheffield City Library, Strafford correspondence, 12/236, as quoted by Slack, op. cit., note 14 above, p. 195.

18 In addition to Guy, op. cit., note 6 above; Razzell, op. cit., note 6 above; Carmichael and Silverstein, op. cit., note 10 above; and Slack, op. cit., note 14 above; other helpful discussions of the history and nature of smallpox include Lise Wilkinson, 'The development of the virus concept as reflected in corpora of studies
} 
the effects of the virus varied so broadly in their seriousness and often remained unidentified, smallpox created none of the disruption and panic associated with the plague. During the severe outbreak of 1634 , for example, a proclamation ironically forbade "any resort to his Majesty's Court, for cure of the King's evil", and a scheduled display of naval force was shifted from Portsmouth to The Downs. Smallpox later combined with the plague in 1641 to disrupt Parliament, and subsequent epidemics in Oxford forced the University to disband temporarily. ${ }^{19}$ But the business of London and the major cities was not disturbed as it was in times of plague, and contemporaries seem to have accepted the disease's inevitability without any signs of public crisis. They did not, however, ignore the threat of smallpox.

Unlike the plague, smallpox became an egalitarian disease. Once again children were most vulnerable to the virus, and they suffered probably the highest mortality rate. Claims that smallpox accounted for up to one-third of all children's deaths in the seventeenth and eighteenth centuries are unverifiable because burial registers did not list causes of death and many infants probably died before the characteristic signs of smallpox were apparent. ${ }^{20}$ Numbers lose their significance, however, in the understated records of the Puritan minister Henry Newcome:

The small-pox raged, and was very mortal; several hopeful children taken away by them. Mr. Edward Greaves's eldest son died Dec 3rd [1680]. Mr. Barlow's eldest son died December 6th. Richard Hanson had but one son, and he died. William Booker buried a very hopeful son December 15 th. Little Sarah Leech, a pretty sweet child of precious Jo. Leeche's, deceased, was buried December 21st. February 15th, Mr. Higinbotham had a little son died also of the same disease. Martha Taylor's son March 2nd. William Hibbert had a child also died of the same distemper April 2nd. ${ }^{21}$

These deaths and the deaths of other children, commonly recorded in journals, memoirs, and letters from the period, are not the losses of the poor and neglected. Smallpox indiscriminately claimed the children of middling, gentry, and noble classes; and it afflicted the adult population as well. A letter from John Chamberlain dated 19 June 1619 succinctly expresses the new reality:

The Lady Delaware likewise lies now sicke of the small pockes, which is somwhat straunge that this disease should now adayes take such hold of persons that for yeares and other respects thought themselves privileged longe since from the boyling and furie of maladies that follow younge bloud. ${ }^{22}$

on individual pathogens', Med. Hist., 1979, 23: 1-28; C. W. Dixon, Smallpox, London, J. \& A. Churchill Ltd., 1962; Derrick Baxby, Jenner's smallpox vaccine, London, Heinemann Education Books, 1981; Frederick F. Cartwright, A social history of medicine, London, Longman Group Ltd., 1977; and Hopkins, op. cit., note 10 above.

${ }_{19}$ The calendar of state papers, domestic, ed. John Bruce, London, HMSO, 1864, 1634-35, vol. 7, p. 357; 1635, vol. 8, p. 14; Letters of Humphrey Prideaux, ed. Edward Maunde Thompson, London, Camden Society, 1875, New Series, 15: 41; Francis P. and Margaret M. Verney, Memoirs of the Verney family, London, Longmans, Green, and Co., 1892-9, vol. 4, p. 385.

${ }^{20}$ Cf. Baxby, op. cit., note 18 above, p. 12; and Razzell, op. cit., note 6 above, pp. 101-39.

${ }^{21}$ Henry Newcome, The autobiography of Henry Newcome, ed. Richard Parkinson, Manchester, Chetham Society, 1852, vol. 2, p. 235.

22 John Chamberlain, The letters of John Chamberlain, ed. Norman Egbert McClure, Philadelphia, American Philosophical Society, 1939, vol. 2, p. 245. 
Later seventeenth-century physicians contended that fewer poor than rich died from this disease "by reason of the narrowness of their circumstances, and ordinary way of living, they have not the means of injuring themselves, as the rich have, by a more elegant diet." 23 Other observers of the contemporary social scene such as John Evelyn and Samuel Pepys noted with similar regularity the cases of smallpox among lords and ladies, courtiers and clergy. Not even royalty escaped. The Venetian ambassador reported in Decmber 1632, "After the king had suffered some slight disturbance spots appeared on his face and neck, indicating either smallpox or over heating of the blood"; and in November 1648 and November 1650 dispatches he noted that "The Prince of Wales and the Duke of York are sick in Holland of the small pox" and that "The Prince of Orange has died of small pox at the age of 26 , after 6 days' illness." 24 His wife Mary and her brother Henry, the daughter and son of Charles I, also died from smallpox soon after the Restoration. Queen Mary succumbed to the same fate in 1694; Queen Anne suffered a severe attack; and the Stuart hopes ended when smallpox took her son. Little could be done to avoid the disease.

Flight was of limited value and isolation impossible. No mass exodus from London is documented, though some inhabitants followed the recourse common during plague. "The small pockes drave the Lord Keper [Thomas Egerton] into the countrie", Chamberlain observed in a letter dated 23 December 1602; and the diaries record instances of similar behaviour. "Hearing the Small-pox was very rife in and about Lond", John Evelyn and his wife left for Tunbridge in June 1652; and Pepys noted in December 1663 that "the young ladies of Hinchingbrooke" were visiting his parents in the country, "their house having the small-pox in it". ${ }^{25}$ But other letters and memoirs document the devotion and futility with which individuals faced the disease. During the rampant outbreak of 1634, Katherine Oxinden expressed the fears " $t$ is so rife that I looke everi day when one of us shale have it an if it be Godes plesure that it must bee so I wolde faine take the likellest corse to keepe the soune from the infachded." ${ }^{26}$ She recognized, however, that no course short of complete isolation could keep him from being constantly brought together with others. When the son of Mary, Countess of Warwick became infected, his mother simply and heroically sent her husband, daughter-in-law, and attendants away while

I shut up myself with him, doing all I could both for his soul and body; and though he was judged by his doctors to be in a hopeful way of recovery, yet it pleased God to take

\footnotetext{
${ }^{23}$ Thomas Sydenham, The entire works of Dr Thomas Sydenham, ed. John Swan, London, 1769, p. 116. In The diary of the Rev. John Ward, A. M., arranged by Charles Severn, London, 1839, the minister and doctor also noted the vulnerability of the rich, "who are much tampered with by clysters and other of the physician's conceits" (p. 264).

${ }_{24}$ The calendar of state papers, Venetian, op. cit., note 6 above, 1632-36, vol. 23, p. 47; 1647-52, vol. 28, pp. 80,159 .

${ }^{25}$ Chamberlain, op. cit., note 22 above, vol. 1, p. 179; John Evelyn, The diary of John Evelyn, ed. E. S. de Beer, Oxford University Press, 1955, vol. 3, p. 68; Samuel Pepys, The dairy of Samuel Pepys, ed. R. C. Latham and W. Matthews, Berkeley and Los Angeles, University of California Press, 1970-83, vol. 4, p. 439.

${ }^{26}$ The Oxinden letters, 1607-1642, ed. Dorothy Gardiner, London, Constable \& Co. Ltd., 1933, p. 94.
} 
him away by death the 16th of May, to my inexpressible sorrow. He wanted about four months of being of age. ${ }^{27}$

John Wandesford's mother was luckier. After her son contracted smallpox from a relative, his mother overcame her great "feare for him" through the greater "caire and paines she tooke about him". As the disease ran its course the daughter, forbidden to see her brother, used the family dog to exchange letters during his isolation and "brought the infection of the dissease upon my selfe". ${ }^{28}$ Contaminated linen, such as John Evelyn slept in, and infected servants-one spread the disease to his daughter-were perils the seventeenth century could not easily avoid. Henry Oxinden might warn a neighbour of disease in his house, and some care could be taken to hire servants who had already recovered from the smallpox, but the predicament the seventeenth century faced is unmistakable. A Northamptonshire man known only as $\mathrm{K}$. Isham wrote, "I have no reason on my own particular to be very secure, having never yet had that almost Universall Disease."29

Increasingly in the seventeenth century smallpox also appeared as the "cruel dissease" and the "grivous disise".$^{30}$ Unlike the plague, whose signs of spreading pestilence warned of danger, smallpox often surprised its victims. At times contemporaries recorded their sense of relief when an illness thought to be the dreaded virus "proved only measles"; 31 more often, as the experience of Mary, Countess of Warwick indicated, the disease struck with unexpected force. "It is usual in the small-pox", the physician-minister John Ward noted in his diary, "for people to alter in half an hour, to bee very well, and all on a sudden to turne." 32 Once the diagnosis was confirmed, medical practice still largely unchanged from the ninthcentury observations of Rhazes and reliant upon "some little preseruatiues, as Vnicornes horne, Bezoard stone, and Cordiall waters" 33 proved of limited use. John Evelyn watched his "poore excellent servant" die from the illness "that by no remedies could be brought out, to the wonder of the Physitians." ${ }^{34}$ With greater hope Lady Verney described the change in her son after the characteristic pustules erupted: "the fisysions sath he is, thinkes bee to god, past all danger. He was extremely ill before the cam forth." The relief, she later ruefully wrote, was premature: 'I cannot say much, my hart being fuller of sory then $i$ can expres to you for my dear childe: The

\footnotetext{
${ }^{27}$ Mary, Countess of Warwick, Autobiography of Mary Countess of Warwick, ed. T. Crofton Croker, London, Percy Society, 1848, p. 29.

${ }^{28}$ Alice Wandesford Thornton described her mother Alice Wandesford's concern in The Autobiography of Mrs. Alice Thornton, Edinburgh, Surtees Society, 1875, p. 33.

${ }^{29}$ Evelyn, op. cit., note 25 above, vol. 2, p. 519; vol. 4, p. 424; Oxinden letters, op. cit., note 26 above, pp. 216-17; Pepys, op. cit., note 25 above, vol. 9, p. 481 (his wife, however, may have had other motives when she dismissed a "handsome maid" and hired "another that was full of the small-pox"); MSS IC/845 in the Northamptonshire Record Office, as quoted by Razzell, op. cit., note 6 above, p. 119.

${ }^{30}$ Evelyn, op. cit., note 25 above, vol. 4, p. 455; Verney memoirs, op. cit., note 19 above, vol. 1, p. 252.

${ }^{31}$ Ralph Josselin, The diary of Ralph Josselin, 1616-1683, ed. Alan Macfarlane, London, Oxford University Press, 1976, p. 628.

32 John Ward, op. cit., note 23 above, p. 265.

33 Jacques Guillemeau, The nvrsing of children, London, 1612, p. 103.

${ }^{34}$ Evelyn, op. cit., note 25 above, vol. 4, p. 357.
} 
sent me worde he was past all danger, and now the tell me he is dede." 35 Among the other contemporary accounts not limited to succinct notations of illness, recovery, and death, the autobiography of Alice Thornton captures in unusual and memorable detail the fears, uncertainties, and suffering that in the seventeenth century accompanied this harrowing and by then commonplace affliction:

Uppon the 29th of September, when I was yett very weake, began my daughter Katte with a violent and extreme pain in the backe and head, with such scrikes and torments that shee was deprived of reason, wanting sleepe, nor could she eate anything. For three daies she contineuded, to my great affliction, not knoweing what this distemper would be. At last the smale pox appeared, breaking out abundantly all over; but in her unguidablenesse stroke in againe, so that my brother Portington used many cordialls to save her life, affter which they appeared, and then we had more hopes, but was in great danger of losseing her sight. She was all over her face in one scurfe, they running into each other. But loe, by the goodnesse of God, for which I humbly blesse and praise His holy name, she passed the danger of death, beginning to heale. Her extreamity beeing soe great, crieing night and day, that I was forced to be removed, though very weake, into the scarlett chamber, for want of rest. ${ }^{36}$

Alice Thornton's description of her daughter Katherine's suffering conveys in immediate, human terms the painful, nightmarish course smallpox could run. The clinical description and numerous illustrations in C. W. Dixon's standard twentiethcentury text Smallpox and the detailed case histories of Theophilus Lobb's eighteenth-century $A$ treatise of the small pox give another view of what the seventeenth century must have feared. Chills, shivering, fever, head and back aches, vomiting, torpor, and convulsions are common symptoms of the disease, but the most frightening sign is the pustules themselves. Although the plague marked many of its victims with the purplish-black buboes or "gods tokens", smallpox wreaked particular havoc. In its less deadly "distinct" kind, according to Thomas Sydenham, "pale red pustules" usually erupted on the fourth day. By the eighth day swelling commonly produced blindness, and the distinctive eruptions

gradually discharge a yellow matter, in colour resembling a honey-comb. The inflammation of the hands and face being in the mean time come to its height, causes the spaces between the eruptions to look of a pretty florid colour, not unlike a damask rose: and in reality the more mild and genuine the small-pox is, so much more the eruptions and their intermediate spaces approach this colour. As the pustules in the face appear rougher and yellower every day as they ripen, so, on the contrary, those of the hands and other parts appear smoother and not so white. ${ }^{37}$

In the dangerous "confluent" form sometimes described by contemporaries as the "flox", the pustules tended to run together, and their colour could turn ominously blue, purple, or black:

The more violent the small-pox proves, the nearer the eruptions, as they ripen, incline to a dark brown colour, and the longer they are in falling off, if left to themselves;

\footnotetext{
35 Verney memoirs, op. cit., note 19 above, vol. 1, pp. 245-6.

36 Thornton, op. cit., note 28 above, p. 157.

${ }^{37}$ Sydenham, op. cit., note 23 above, pp. 97-8.
} 


\section{Smallpox in seventeenth-century English literature}

whereas contrariwise the less they run together, the yellower they grow, and the sooner they scale off. When this pellicule, or scab, which covers the face first falls off, it leaves no roughness behind, but it is immediately succeeded by branny scales, of a very corrosive nature, which not only make larger pits than the distinct kind generally do, but also much disfigure the face with unseemly scars. And in the confluent kind, if the disease has been very violent, the skin of the shoulders and back sometimes scales off, leaving these parts bare. ${ }^{38}$

Besides the unpleasant appearance and the great suffering they produced, the pustules also exuded a distinctly foul odour or "noysomenesse", as John Evelyn matter-offactly described the symptoms of his own infection. ${ }^{39}$ And when they did not signal a hopeless prognosis, the running pustules often foretold the terrible aftermath.

Smallpox marred those who survived in ways the plague did not. Alice Thornton tried to face this prospect in an entry describing her daughter's recovery:

About November she went abroad in the house, only losst by this sicknesse her faire haire on her head, and that beautifull complection God had given. The Lord suply her soule with the comelinesse of His grace and spirit in her heart, makeing her lovely in His sight. ${ }^{40}$

How common this disfigurement was in the seventeenth century is not known. A chapter on smallpox in the 1612 English translation of Jacques Guillemeau's The nvrsing of children insists,

For dailie experience sheweth vs, that many die thereof. ... Others haue lost their eyes: or at the least there hath remayned some pearle, or spot vpon them: Others haue had their eyes staring, red, or watring: Some haue been deafe, and dull of hearing: Others haue had their nose and mouth shrunke together, or else pufed vp: and some haue been hoarse afterwards all their life time: The least accident of all is, that many haue remained disfigured with pits and holes in their faces. ${ }^{41}$

Charles Creighton's imaginative study of the London Gazette concluded that perhaps twelve to sixteen per cent of London's inhabitants were marked by smallpox. ${ }^{42}$ Modern studies play down the extent to which the disease permanently disfigures, contending that, in time, children in particular recover quite completely from the initial, unsightly effects. But seventeenth-century treatises emphasized, among smallpox's "many other Evils", the "foul scars and pits in the Skin"; 43 and Alice Thornton was not alone in her brave struggle to accept the immediate and long-term effects of the disease that could strike all but the five per cent who were naturally immune.

Seventeenth-century letters, memoirs, and diaries personalize the mounting figures in the Mortality Bills. Not all families were as fortunate as that of Ralph Josselin, four of whose children survived the smallpox. John Chamberlain's letter to Sir Dudley

38 Ibid., p. 100.

${ }^{39}$ Evelyn, op. cit., note 25 above, vol. 2, p. 522.

40 Thornton, op. cit., note 28 above, p. 157.

${ }^{41}$ Guillemeau, op. cit., note 33 above, pp. $110-1$.

42 Creighton, op. cit., note 10 above, vol. 2, pp. 453-6. Creighton counted the number of times the effects of smallpox were noted in descriptions of runaways and other wanted citizens of London.

43 Daniel Phillips, A dissertation of the small pox, trans. T. E., London, 1702, p. 47. 
Carlton informed him that Viscount Lisle "hath lost his eldest sonne Sir William Sidney of the small pockes, which were well come out and yet he went away on the sodain; he hath now but one sonne left." Other letters relate the deaths of the oldest son of Sir William Bowier, who left a child and a "younge widow"; the only son of Lady Veres, "a very proper and towardly young gentleman of some two and twenty yeares"; and the only child of Lord Darcie, "a very proper and hopefull younge gentleman of some 22 yeares, and was shortly to marrie Sir Fraunces Vanes daughter a daintie gentlewoman in all respects." 44 In his autobiography, William Stout described the sorrow that overwhelmed his mother when her two youngest sons died of smallpox soon after their father:

The loss of these two children, so near together and so soon after their father, was so [?great an] affliction to my mother that she continued in much sorrow for a long time; as was also my sister, which added to her other bodily infirmities, reduced her very low. ${ }^{45}$

Adam Martindale grieved the loss of a promising son "too forward to live", who seemed to be recovering from the illness and then suddenly "grew very ill, and rushing up in the panges of death his mother asked him what he would doe; he answered he would pray, and accordingly did, and then immediately threw himselfe downe upon his bed and died." 46 With greater poignancy John Evelyn uttered the "unspeakable sorrow \& Affliction" caused by the loss of his favourite daughter Mary, who died from smallpox at the age of nineteen. In a long, elegiac passage unusual for him, Evelyn lamented, "O deare, sweete and desireable Child, how shall I part with all this goodnesse, all this Vertue, without the bitternesse of sorrow, and reluctancy of a tender Parent!" Within six months on the same day in the week a second daughter succumbed to smallpox; later his grandson and remaining male heir contracted the disease and a "young \& very hopefull" kinsman died from it. ${ }^{47}$

Neither these reactions nor the moving responses of Mary, Countess of Warwick and Ann, Lady Fanshawe support the widely accepted modern belief that the high mortality rate among infants and children in the seventeenth century inured parents to their children's deaths. When "it pleased God to take" her only son just before he came of age and despite her efforts to save him, the Countess of Warwick wrote that her "sad and afflicted husband ... cried out so terribly that his cry was heard a great way; and he was the saddest afflicted person could possibly be." Her own actions left her sorrow unstated yet obvious: she "instantly" left her house in Lincoln's Inn Field "and never more did I enter that house; but prevailed with my Lord to sell it."48 When Lady Fanshawe's three oldest children had smallpox, her grief over the death of her only son Richard caused her to miscarry; still greater sorrow is evident in her description of her nine-year-old daughter Ann's later suffering.

\footnotetext{
${ }^{44}$ Chamberlain, op. cit., note 22 above, vol. 1, pp. 397, 497; vol. 2, pp. 526, 555.

45 William Stout, The autobiography of William Stout of Lancaster, 1665-1752, ed. J. D. Marshall, Manchester, Chetham Society, 1967, p. 76.

${ }^{46}$ Adam Martindale, The life of Adam Martindale, ed. Richard Parkinson, Manchester, Chetham Society, 1845 , pp. 108-9.

${ }^{47}$ Evelyn, op. cit., note 25 above, vol. 4, pp. 424, 464; vol. 5, pp. 431, 520.

48 Warwick, op. cit., note 27 above, pp. $30-1$.
} 
She lay sick but five dayes of the small pox, in which time she expressed so many wise and devout sayings as is a miracle from her years. We both wished to have gone into the grave with her. She lyes buryed in Tankersley Church, and her death made us both desirous to quit that fatall place to us. ${ }^{49}$

None of these poignant expressions of grief confirms Philippe Ariès's influential suggestion that parents sought refuge from pain and sorrow in a deliberate indifference to the danger of death so commonplace among their children. ${ }^{50}$ The grief of both mothers and fathers, on the contrary, suggests an emotion only partly accountable by Lawrence Stone's controversial view of the period's gradual transition from the "Restricted Patriarchal Nuclear Family" to the "Closed Domesticated Nuclear Family". 51 In their understated eloquence, the sufferings of these parents are as heartfelt as any Stone found for the later years of allegedly growing family importance. Perhaps, as he and others have suggested, the economic, humanistic, and religious forces of the Renaissance helped to shape the sensibilities that gave new importance to the value of the family as well as the individual. But perhaps the grief is instinctive.

Smallpox, in any case, touched many families deeply. Its survivors were often left to struggle with the psychological as well as the physical scars of the disease. In an almost offhand manner, John Chamberlain described a fate many came to fear:

I know not whether I wrote the decease of Lady Wallop, or that the Lady Stewkely with tending her sonne tooke the infection so strongly that she was at the last cast but is now upon recoverie though she be pittifully peppered and in daunger to be shrewdly disfigured.

Elsewhere he callously related that smallpox had "so seasoned" Lady Bedford "that they say she is more full and fowle then could be expected in so thin and leane a body"; it also "seased on the Lady Mordant . . . with great daunger to marre her faire face." 52 Pepys's gossip about the Restoration years also contains, among its references to smallpox, news of Lady Richmond's illness, "by which all do conclude she will be wholly spoiled". A later diary entry tactfully records, "here did see my Lady Richmond, who is I believe of a noble person as ever I see, but her face worse then it was considerably, by the smallpox."53 The disease also spared neither the face of the famous Lady Mary Wortley Montagu nor the complexions of the relatively unknown. ${ }^{54}$ The autobiographical account of Alice Thornton describes her brother as

\footnotetext{
49 Anne, Lady Fanshawe, The memoirs of Anne, Lady Halkett and Anne, Lady Fanshawe, ed. John Loftis, Oxford University Press, 1979, p. 136.

${ }^{50}$ Phillipe Ariès contended in Centuries of childhood that "People could not allow themselves to become too attached to something that was regarded as a possible loss" (p. 38). Dr W. F. Bynum kindly called my attention to Michael MacDonald's criticism of Ariès's position: in Mystical Bedlam, Cambridge University Press, 1981, particularly pp. 75-85, MacDonald questioned the prevalence in the seventeenth century of "emotional austerity and indifference to members of the immediate family".

${ }_{51}$ Lawrence Stone, The family, sex and marriage in England, 1500-1800, New York, Harper \& Row, 1977.

52 Chamberlain, op. cit., note 22 above, vol. 2, pp. 532, 244-5, 432.

53 Pepys, op. cit., note 25 above, vol. 9, pp. 134-5, 294.

54 Robert Halsband discussed the impact of smallpox on Lady Montagu in 'New light on Lady Mary Wortley Montagu's contribution to inoculation', J. Hist. Med., 1953, 8: 391-2. He incorporated this in his later biography of the woman who helped to popularize inoculation.
} 
"very much disfigured, haveing bin a very beautifull child"; another entry relates that some twenty years later her son Robin "was not soe much disfigured as his sister Kate. But he never recovered his sweete, beautifull favour, and pure couler in his cheeks; his face grew longish; his haire did not fall off." 55 The Verney memoirs also contain the news from Lady Sussex that her daughter Nan had passed the crisis, "and the till me the think, she will not have much disfiger, i pray God, keep us all from it." When smallpox struck closer to home, Lady Verney sent for a special medicine to aid her daughter Mary's recovery: "It is very safe, \& never any peted [pitted] that yused it. Both Mrs. Abell's sisters yused it, and were very full." Mary fortunately recovered "without any inconveniency to her complexion", though the medicine was probably of doubtful value. ${ }^{56}$ Medical research has still to explain why smallpox tends to disfigure primarily the face and hands, and the most advanced seventeenth-century observations found no value in attempts to prevent disfigurement, ${ }^{57}$ but fears drove many to seek the various ointments and nostrums promoted as safeguards against the dreaded scarring. Opening the pustules with golden or copper pins, covering the face and hands with clothing, and anointing the affected areas with a feather or linen cloth dipped in oils of almonds and other compounds probably, at best, gave the illusion of control and the promise of hope in very horrifying circumstances.

Besides the incalculable psychological effects from a disfigured face and its implicit denial of individuality, smallpox threatened the future prospects of many by literally and figuratively marring marriages. The oldest son of Sir Edward Onslow left his newly married wife, acccording to Chamberlain, "a maiden widow, for he fell sicke the first night of the small pockes that tooke him away in few dayes." Another marriage Chamberlain wryly described fared only somewhat better: "Our new bride-groome Sir John Smith is arrested by the small pockes, and his Lady Isabella forgetting her late promise of better or worse in sicknes and health is fled to save her faire skin." His letters sardonically recognize the marital game dictated by the economic and social realities of the seventeenth century. "The Lady of Suffolke is sicke of the small pockes," he noted in a telling sentence, "which wold have don her more harme fortie yeares ago than they can do now." Chamberlain was realistic, not unduly cynical, in his recognition that beauty was a commodity to be weighed as well as a virtue to be praised. He stated without comment that the marriage between the daughter of Lord Burghley and the second son of the Lord Chamberlain "is like enough to go forward, yf the small pockes which have lately seased on her do not marre the match." He may have shown little sympathy, but he was not atypical in his awareness that marriages were indeed financial matches. When Lord Delaware's daughter, a woman Chamberlain described as "one of our prime and principall bewties", was stricken by smallpox, he realistically remarked, "yf they deale not mercifully with her she is quite undon, seeing her goode face is the best part of her fortune." 58 Though his letters may

\footnotetext{
55 Thornton, op. cit., note 28 above, pp. 33, 158.

56 Verney memoirs, op. cit., note 19 above, vol. 1, p. 252 ; vol. 4 , p. 51.

${ }^{57}$ Hopkins, in op. cit., note 10 above, p. 5, noted the medical mystery. Simon Kellwaye, for example, confessed that he "neuer coulde finde any thing that did perfectly content me" (op. cit., note 11 above, p. $47 \mathrm{v}$.).

${ }^{58}$ Chamberlain, op. cit., note 22 above, vol. 2, pp. 44, 208, 216-17; vol. 1, p. 513; vol. 2, p. 184.
} 
affect the indifference of a jaded court observer, they express the daily fears that attended smallpox.

Love might conquer but was not exempt from these fears. In her Memoirs of the life of Colonel Hutchinson, Lucy Hutchinson recalled that on the day her marriage negotiations were completed she became ill from smallpox "which was many wayes a greate triall upon him." The danger to her life was not the only anxiety her future husband endured; Lucy added that the disease "made her the most deformed person that could be seene for a greate while after she recover'd." Her insistence "Yett he was nothing troubled at it, but married her assoone as she was able to quitt the chamber" is a testimony to her husband's great love; and her assurance "God recompens'd his justice and constancy by restoring her" further testifies to a happy union sanctified by divine blessing. ${ }^{59}$ Implicit in the memoir is Lucy's recognition that no one would have blamed John Hutchinson if he had broken the marriage agreement. The reality appears in the similar circumstances that befell Dorothy Osborne and William Temple. Dorothy's famous letters tell of the romantic love between two people who overcame the obstacles to their relationship; Lady Giffard's life of her brother William describes the final trial. A week before the marriage was to take place smallpox struck Dorothy as dangerously as it had Lucy Hutchinson: "she fell soe desperately ill there was little hopes of her life". Again tragedy was averted and love reaffirmed. William Temple was, in his sister's view, "happy" when he realized that Dorothy's life had been saved, "his kindness haveing greater tyes then that of her beauty though that Loss was too great to leave him wholy insensible. He saw her constantly while she was ill, \& married her soon after."60 Lady Giffard was not, of course, looking at Dorothy through her brother's eyes of love; and she could voice the fears that lay beneath the surface of Lucy Hutchinson's narrative. The seventeenth century may have seen, as Lawrence Stone and others have contended, the emergence of the "companionate marriage" often based on romantic love;" pragmatic considerations, however, were still very much a part of the prevailing attitude.

Ultimately individuals for whom smallpox had become an ever-constant danger fell back upon faith - faith in love and, not surprisingly, faith in God. Throughout the autobiographies, diaries, and memoirs the phrases "God was pleased", "Godes pleasure", and "it pleased the Lord" provide reassuring tags. The smallpox that struck Francis Higginson's daughter as the family sailed from England to Massachusetts was accepted because "it was God's will the child die about six of the clock at night". ${ }^{2}$ The mercy of God was relied upon as well to replace the marred complexion with an inner beauty and to withdraw His hand from the vexing visits of smallpox. Adam Martindale's faith helped him overcome the horrors of a disease that

\footnotetext{
${ }^{59}$ Lucy Hutchinson, Memoirs of the life of Colonel Hutchinson, ed. James Sutherland, London, Oxford University Press, 1973, p. 33.

${ }^{60}$ Lady Giffard's account is found in The letters of Dorothy Osborne to William Temple, ed. G. C. Moore Smith, Oxford University Press, 1928, rpt. 1959, p. 184.

61 The phrase Stone used in Family, sex and marriage, op. cit., note 51 above.

${ }^{62}$ Francis Higginson, Letters from New England, 1629-1638, ed. Everett Emerson, Amherst, University of Massachusetts Press, 1976, p. 16, as quoted by T. E. Cone, Jr. in 'The Reverend Francis Higginson describes his young daughter's death from smallpox on board a ship bound for Massachusetts in 1629', Pediatrics, 1978, 61: 192.
} 
left him blinded for several days: "it pleased God to preserve both mine eyes, and (which was the greater wonder, though lesse materiall), though my face, when the scabs were peeled off, remained for a long time full of red spots, it was not at all pitted."63 But faith was not always perfunctory and obligatory; the tensions of the sufferings are sometimes not concealed. An entry for 3 November 1678 in Ralph Josselin's diary suggests that even the pious minister could momentarily falter: "Bettie having the small pox, it found mee in an ill frame and entred deepe into mee, but my heart returned into god with hope that he will bee gracious, a cheerfull summer day."64 After the death of his second daughter resolve came less readily to John Evelyn. Though the words in his diary on 28 August 1685 invoke biblical reflections of infinite mercy and vales of misery, the reality and the reassurance do not firmly join in the conclusion:

thus in lesse than 6 moneths were we depriv'd of two Children for our unworthinesse, \& causes best known to God, whom I beseech from the bottome of my heart that he will give us grace to make that right use of all these Chastisements that we may become better, and entirely submitt [in] all things to his infinite wise disposal. ${ }^{65}$

Several decades later, individuals found renewed comfort and faith in the safety provided by inoculation; seventeenth-century contemporaries of John Evelyn for the most part could only submit to the suffering God had ordained. Their fears and hopes were expressed by the group of writers to whom their society traditionally turned for guidance, the men and women who sought through poetry to come to terms with the ubiquitous disease.

\section{III}

Most of these poetic responses to smallpox, like Dryden's memorial to Lord Hastings, convey the grim truth so common to seventeenth-century memoirs, tracts, and diaries: whilst recovery from the disease occasioned some of the poems, the majority are elegies. Not all consciously imitate the formal patterns of lament, praise, and consolation, but in their often exaggerated expressions of grief, the poems seem more studied and artificial than the autobiographical prose. Unlike the intimate, spontaneous disclosures evident in works apparently intended neither for circulation nor for publication, the large number of commemorative volumes issued at the universities and the various elegies commissioned by patrons appealed to a public community of mourners. Poets who knew the deceased slightly, if at all, tended towards a Renaissance reluctance to display personal sorrow in the elegy; ${ }^{66}$ however here, as well as in the other nonelegiac poems on smallpox, their apparent detachment and strained wit often, paradoxically, suggest engagement. Whether they mourned

\footnotetext{
${ }^{63}$ Martindale, op. cit., note 46 above, p. 19. See also The history of the life of Thomas Ellwood, Philadelphia, n.d., p. 119.

64 Josselin, op. cit., note 31 above, p. 615.

${ }^{65}$ Evelyn, op. cit., note 25 above, vol. 4, p. 464.

${ }^{66}$ G. W. Pigman III argued in Grief and English Renaissance elegy, Cambridge University Press, 1985, that Renaissance elegists only gradually overcame a reluctance to publish poems that express "sincere sorrow".
} 
the deaths of a smallpox victim or consoled someone afflicted by the disease, their poems cannot escape the personal horror so evident in the everyday lives of the seventeenth century.

Indeed, by their very nature the smallpox poems are distinctly preoccupied with the causes of suffering, misery, and death. Seventeenth-century poems about diseases, whether elegies or occasional pieces, are surprisingly uncommon. Milton's well-known though minor 'On the Death of a Fair Infant Dying of a Cough', in fact, is unusual; most elegies do not mention the cause of death. Poems about everyday afflictions are also quite rare. Aside from the verse prompted by John Denham's syphilis and circulated among his friends, isolated poems on the fever, ague, toothache, and impostume were published infrequently in the seventeenth century and tend to be associated with a few writers drawn to the subject of diseases. On those occasions when the nature of death or the cause of illness is considered, the explicitness of the diaries and memoirs is missing. One striking exception, William Browne's epitaph on the seven-year-old "Faire Canace", nonetheless retains a general quality:

Then death the kind was worse, what did infect,

First seas'd her mouth, \& spoil'd her sweet aspect:

A horrid Ill her kisses bitt away,

And gaue her almost liples to the Clay.

If Destinye so swift a flight did will her,

It might haue found some other way to kill her;

But Death first strooke her dumb, in hast to haue her,

Lest her sweet tongue should force the Fates to save her. ${ }^{67}$

The graphic description leaves the disease unnamed as the epitaph develops a macabre wit suited to the elegiac moment. Browne's poem lacks an immediacy so apparent in the physician Martin Lluelyn's description of Henry, Duke of Gloucester's fatal struggle with smallpox:

The sharp disquiets of an aking brain,

A heart in sunder torne, yet whole to pain.

Eyes darting forth dimme fires, instead of sight;

At once made see, and injur'd by the Light;

Faint pulse; and tongue to thirsty cinders dry'd:

When the reliefe of thirst must be deny'd.

The Bowels parcht, limbs in tormenting throwes

To coole their heat, while heat from cooling growes.

Slumbers which wandring phansies keep awake,

And sense not lead by objects, but mistake. ${ }^{68}$

No other poem on smallpox rivals Lluelyn's clinical sense of the affliction, but as a group the smallpox poems, almost alone among the period's poetry, confront disease as a major source of suffering and death.

\footnotetext{
${ }^{67}$ William Browne, 'An epitaph', in The whole works of William Browne, ed. W. Carew Hazlitt, London, 1869 , p. 341 .

${ }^{68}$ Martin Lluelyn, An elegie on the death of the most illustrious prince, Henry Duke of Gloucester, Oxford, 1660 , pp. 4-5.
} 
They do so with the seventeenth-century insistence that smallpox is a "Cruel and vnpartiall Sicknesse". ${ }^{69}$ For poets as diverse as Ben Jonson and Thomas Shipman the contagion sweeping the seventeenth century was an "Envious and foule Disease" that often brought "Most cruel Death" ${ }^{70}$ Theirs was not the metaphoric meaning Susan Sontag found in dreaded disease; they did not fashion figurative embodiments of evil in which the ills of society are "projected onto a disease" and "the disease (so enriched with meaning) is projected onto the world." Nor did the seventeenth-century view of smallpox show the "profound disequilibrium between individual and society" Sontag's Illness as metaphor found in the twentieth century, or the feeling of "some general aberration or public calamity" it detected in the Elizabethan era. ${ }^{71}$ Quite unlike the vision of the plague seen in the contemporary works of Dekker, Taylor, and Wither, the view of smallpox in the poems sees no divine punishment for some "Capitall offence, / Some high, high Treason". ${ }^{72}$ With the century's other victims of this "offensive race" the poets agreed that the illness was a "fierce disease, which knows not how to spare / The young, the great, the knowing, or the Fair."73 Part of an unjust, unknowable, and most "hard-hearted Fate", the disease appeared to destroy with indiscriminate impunity. "It hath no eare to lend our groans", Arthur Brett voiced a lament heard earlier in tracts and memoirs,

Heares nor for poor, nor mighty ones,

To neither place, nor person shuns,

To cottage and to pallace runs,

And puffs out smaller starres, and blowes out Suns. ${ }^{74}$

Smallpox came upon the unaware like an assassin in the night, "It seemeth this, it seemeth that"; ${ }^{75}$ and the insidiousness of its attack was rivalled only by the cruelty of its effects. "A Disease / That Scandals Galen and Hippocrates", the fierce, remorseless smallpox the poets decried was "so lothsome too, the Soul would hardly own / The Body at the Resurrection". ${ }^{76}$

The occasional nature of the elegies encouraged mourners to express the communal dismay, fear, and grief aroused by the senseless, wanton loss. Poems on the deaths of royalty, aristocracy, and commoners alike traditionally voice the betrayal of those

\footnotetext{
69 Thomas Spilman, 'Vpon his ladies sicknesse of the small pockes', in A poetical rhapsody, 1602-1621, ed. Hyder E. Rollins, Cambridge, MA, Harvard University Press, 1931, vol. 1, p. 222.

70 Ben Jonson, 'An epigram. To the small pox', in Ben Jonson, ed. C. H. Herford and Percy and Evelyn Simpson, Oxford University Press, 1947, repr. 1954, vol. 8, p. 188; Thomas Shipman, 'Beauty's enemy', in Carolina: or, loyal poems, London, 1683, p. 78.

${ }_{71}$ Susan Sontag, Illness as metaphor, New York, Farrar, Straus and Giroux, 1978, pp. 58, 75.

72 The lines are from Thomas Dekker's Nevves from Graues-end (1604); they are included along with a number of other similar statements in J. Milton French's edition of George Wither's The history of the pestilence, op. cit., note 15 above, pp. $\mathrm{xx}-\mathrm{xxiii}$.

${ }^{73}$ Katherine Philips, 'On the death of my Lord Rich, only son to the Earl of Warwick, who died of the small-pox, 1664', in Minor poets of the Caroline period, ed. George Saintsbury, Oxford University Press, 1905, vol. 1, p. 583.

${ }^{74}$ Arthur Brett, Threnodia. On the death of the high born Prince Henry, Duke of Gloucester, Oxford, 1660, p. 12.

75 Ibid., p. 5.

${ }^{76}$ Henry Bold, 'Elegy on the death of Her Highness Mary Princess Dowager of Aurange', London, 1660, broadside.
} 
who had been "cruelly surpris' $d$ ". ${ }^{77}$ In these elegies and in other poems on the sickness, the treacherous onslaught of the disease especially disturbed poets who had seen smallpox vent its spite with particular malice on the undeserving. Dryden's bitter denunciation of the unjustness with which smallpox spared the dissolute and destroyed the promising seeks an emotional release similar to the displacement sought in Ben Jonson's and Richard Corbett's excoriations of the disease. His burst of unanswered questions about the justice of Lord Hastings's death and their satiric flights against the cruel and spiteful illness attempt to counter the threat of smallpox with an outpouring of emotion. Indignation and outrage prompted the curses of Jonson and Corbett; "Grief makes me rail", Dryden admitted, and "Sorrow will force its way" (p. 5). Others less aggressively and less defensively attempted to reconcile themselves to the inexplicable and malevolent disease that appeared to them, as the title of a piece on the death of Princess Mary indicates, as 'Beauty's Enemy'. ${ }^{78}$

None achieved the simple acceptance of Thomas Nashe's 'A Litany in Time of Plague'. Unlike Nashe, who fell back upon the traditional premise that mortality destroys that which society values most dearly, the poets decrying smallpox found little comfort in the knowledge that "Beauty is but a flowre, / Which wrinckles will deuoure" or that "Brightnesse falls from the ayre". ${ }^{79}$ They understood too intensely the premature loss of beauty caused by smallpox when they beheld

in many a pityed face

Those hatefull pits and furrowes of its trace,

What pumices it leaues of Cheek and Lip

Beyond all cure of female workmanship. ${ }^{80}$

None expressed the letters' and memoirs' blatant acknowledgement of the social value of physical attractiveness, but the importance of beauty in both the poetry and society of the seventeenth century is unmistakable:

Oh thou deform'd unwoeman-like Disease,

That plowst up flesh and bloud, \& there sow'st pease,

And leav'st such printes on Beauty, that dost come

As clouted shon do on a floore of lome;

Thou that of faces hony-combes dost make,

And of two breasts two cullenders. ${ }^{81}$

77 The phrase is from Philips's elegy on Lord Rich's son (see note 73 above). Examples of tributes to commoners and royalty can be found in Samuel Holland's 'On the untimely and much lamented death of Mrs Anne Gray, the daughter of the learnedly accomplisht Doctor Nicholas Gray of Tunbridge in Kent', in A century of broadside elegies, ed. John W. Draper, London, Ingpen and Grant, 1928, p. 71; and in the university commemoratives to Queen Mary, Lacrymae cantabrigienses, Cambridge, 1695.

78 Jonson, 'An epigram. To the small pox' and 'To sicknesse', op. cit., note 70 above, vol. 8, pp. 181, 104; Richard Corbett, 'An elegie upon the death of the Lady Haddington who dyed of the small pox', in The poems of Richard Corbett, ed. J. A. W. Bennett and H. R. Trevor-Roper, Oxford University Press, 1955, pp. 59-62; Shipman, 'Beauty's enemy', op. cit., note 70 above, pp. 78-9.

79 Thomas Nashe, from Summers last will and testament and entitled 'A litany in time of plague' by modern anthologists, The works of Thomas Nashe, ed. Ronald B. McKerrow, Oxford, Basil Blackwell, 1958, vol. 3, p. 283.

${ }_{80}$ Thomas Lockey, 'Though we triumph, and that our muse doth sing', in Musarum oxoniensium pro rege svo soteria, Oxford, 1633, sig. G4r.

${ }^{81}$ Corbett, 'An elegie', op. cit., note 78 above, p. 61. Part of this poem, including these lines, appears under the title 'On a Lady that dyed of the small pox', in Parnassus biceps or several choice pieces of poetry (1656). 
Smallpox could, in Jonson's phrase, "nullify a face", a fear natural in a period that had only recently "no longer felt, deep down, that the image was the person, and that defacing the image magically caused actual harm." 82 John Oldham admitted as much in his description of the sickness that killed his friend Charles Morwent:

All the staid glories of thy face,

Where sprightly youth lay checked with manly grace,

Are now impaired,

And quite by the rude hand of sickness marred. ${ }^{83}$

Though the poem maintains a distinction between the body and the soul, insisting that Morwent radiates his essential virtue despite physical deformity, the passage admits an inextricable relationship between appearance and identity. Indeed, the numerous attempts to transform if not deny the ravages of smallpox reveal the various poems' preoccupation with the fear of annihilation implicit in disfigurement.

Some simply refused to acknowledge the cruel triumph of the disease. William Hammond's poem to Thomas Stanley ends with the consolation, "What though she pit thy skin? She only can / Deface the woman in thee, not the man." 84 As the unknown author of another piece included in $A$ poetical rhapsody argued, physical beauty is valued among the "sweet Sex"; a "Pocke-hol'd face" cannot detract from the masculine attractiveness of valour and wit. ${ }^{85}$ And when the thousand wounds of the disease's shafts proved fatal, men were consoled that their "untouched grace" would live beyond the assault. The enemy may strike the heart, William Strode wrote in a common military metaphor,

yet none could make a breach

Into his soule, a soule more fully drest

With vertuous gemmes than was his body prest

With hatefull spotts. ${ }^{86}$

Though women also outfaced the weapons of smallpox, the triumph of their virtue did not always give similar comfort in a culture that clearly admired feminine beauty. Thomas Spilman tried to accept the attack on his beloved by vowing to wear in his bosom the "ritch spoyles" the sickness would seize, "And close locke them in my hart"; ${ }^{87}$ less romantic poets often sought to mute the troubling disfigurement of both women and men through wit.

For some poets a witty admission of the ravages disarmed smallpox's power to

\footnotetext{
82 Norman N. Holland's summary in Laughing: a psychology of humor, Ithaca, Cornell University Press, 1982, p. 55, of a position Ernest Kris developed in Psychoanalytic explorations in art.

${ }^{83}$ John Oldham, 'To the memory of my dear friend, Mr. Charles Morwent', in The poetical works of John Oldham, ed. Robert Bell, London, 1854, p. 39.

${ }^{84}$ William Hammond, 'To the same, recovered of the small-pox', in Caroline poets, op. cit., note 73 above, vol. 2, p. 501 .

85 'Elegie. III: For what cause he obtaines not his ladies fauour', in A poetical rhapsody, op. cit., note 69 above, vol. 1 , p. 93.

${ }^{86}$ William Strode, 'On Sir Thomas Savill dying of the small pox', in The poetical works of William Strode, ed. Bertram Dobell, London, 1907, p. 87.

${ }^{87}$ Spilman, 'Vpon his ladies sicknesse', op. cit., note 69 above, vol. 1, p. 222.
} 
unsettle. An epitaph on the unknown Mr Bridgeman, for example, typically strains to undo the scars and the victory of smallpox through forced wordplay. The self-conscious pun and epigrammatic closure lessen anxiety in the release of wit, minimizing the threat to the self: ${ }^{88}$

One pitt containes him now that could not dye

Before a thousand pitts in him did lye;

Soe many spotts upon his flesh were shewne

'Cause on his soule sinne fastned almost none. ${ }^{89}$

Pits and holes in the faces of women also inspired poets familiar with the standard gestures of Petrarchan and courtly compliment. Even in the hands of the minor poet Thomas Philipott, disfigured countenances do not remain the burial place of beauty; once smooth and ivory complexions become graves for the hearts of those slain by love:

Each hole may be a Sepulcher,

Now fitly to inter

Those, whom her coy disdaine,

And nice contempt, has immaturely slaine.

The wit in this and similar responses to "Beauties sad decay" lies in an ingenuity that flirts with the literal and the macabre. Philipott in the end manages to avoid the grotesque and to gain his desired effect:

That moysture shall enbalme 'hem, I

Will powre from either eye,

So that those scars she weares,

Shall need no other Ceruse, but my teares. ${ }^{90}$

Not all such studied transformations successfully mediate the fearsome and the witty.

Poets who valued far-fetched metaphors and sudden turns were especially prone to metamorphoses that transformed the horrible into the ridiculous. Often the difference between success and failure depends upon the ability to play within readily accepted conventions and beliefs. In the slight piece 'On a Gentlewoman struct blind with the small Pox', the fanciful suggestion that beauty's sun has been eclipsed in blindness only to become a celestial star to guide all lovers deftly turns the conventional hyperbole of courtly compliment to its advantage. ${ }^{91}$ A similar stellification in 'On Sir Thomas Savill Dying of the Small Pox' gains its satisfying closure from epigrammatic lines that turn easily on the distinction between the virtuous, jewel-like soul and the marred body: "and therefore every scarr / When death itselfe is dead shall be a starre."92 When poets insisted, however, that the pustules on the face of Charles I

${ }^{88}$ In his chapter on the psychology of laughter, Holland has discussed theories, including Kenneth Burke's, that recognize this function of laughter (op. cit., note 82 above).

${ }^{89}$ Strode, 'Epitaph on Mr. Bridgeman', op. cit., note 86 above, p. 87.

90 Thomas Philipott, 'On a gentlewoman much deformed with the small pox', in Poems (1646), ed. L. C. Martin, Welwyn Garden City, Herts., University Press of Liverpool, 1950, p. 3.

91 Ibid., pp. 18-19.

92 Strode, 'On Sir Thomas Savill', op. cit., note 86, above, p. 87. 
were "small Starres to shew him Heavenly" and turquoises sent by heaven "To shew the ill, not make it", 93 the fancy strains unduly after the resemblance. An elegy on Lady Newburgh also struggles rather lamely to reach the conclusion, "We are beguil'd, / Thou were Enammel'd rather than Defil'd."94 Neither conceit was unique to the poems, and each plays a central role in John Oldham's painstakingly written elegy on Charles Morwent, ${ }^{95}$ but they fail for some of the same reasons that Dryden's lines on Lord Hastings falter.

The noisomeness of both distinct and confluent smallpox resists imaginative transformation, particularly when the wit seems forced, and the poems do not always avoid the grotesque. Seventeenth-century poets accustomed to the distorted and revolting imagery fashionable in a tradition of ironic, mocking poems of praise might, of course, simply have been less squeamish or more callous than modern readers; the physician Thomas Sydenham, it may be recalled, had no reservations about likening the colour of the skin between the pustules to a damask rose and comparing the fluid they emitted to a honeycomb. The intention of the smallpox poets and the context of their poems, however, do not always support similarly fanciful descriptions. Though they may on occasion have chosen images as outrageous as any in the verses of mock praise, their primary intention was neither witty exhibitionism nor detached objectivity. When Dryden likened Lord Hastings's smallpox first to rose-buds and then successively to gems and stars, he obviously wanted to transform the terrible disease into something more acceptable. Carried away by wit, he lost the fancy in literal-mindedness. The inflamed pustules suggest, to be sure, some physical semblance to rose-buds, gems, and stars; but the appalling eruptions have none of the beauty and value traditionally associated with these images. Dryden and others like him, Samuel Johnson would have said, tried to be new without being natural; and they also appear to have disregarded the decorous solemnity required by the elegiac occasion. Dryden further showed questionable taste in assuming that readers would see in the oozing, pus-filled lesions tearfully repentant rebels-a comparison he deliberately seems to have pressed. Perhaps the self-conscious forcing of the conceit betrays juvenile insensitivity, but its grotesqueness may also have been a not-entirely-satisfying defense against the physically abnormal and the emotionally troubling.

This may partly explain why poets persisted in these witty metamorphoses despite an awareness of the limitations. To one contemporary their "vain Fancies" appeared an inexcusable breach of decorum:

tis a Sin to be

A witty praiser of a Misery.

Like those hard Wits, who name the Scars

Upon her Face, Ennamel, and bright Stars. ${ }^{96}$

\footnotetext{
93 Jeremy Terrent, 'Thankes for this great deliverance, say you', and William Cartwright, 'I doe confesse the over-forward tongue', in Musarum oxoniensium, op. cit., note 80 above, sigs. G3v. and G3r.

94 William Cartwright, 'On the Lady Newburgh, who dyed of the small pox', in The plays and poems of William Cartwright, ed. G. Blakemore Evans, Madison, University of Wisconsin Press, 1951, p. 544.

95 Op. cit., note 83 above.

96 Thomas Shipman, 'Beauty's enemy', op. cit., note 70 above, p. 78.
} 


\section{Smallpox in seventeenth-century English literature}

Thomas Shipman had no sympathy for those who exploit occasions of sorrow to flaunt their poetic prowess. By the end of his contribution to the commemoration of Princess Mary, however, he seems to have forgotten his own criticism. Death assumes the familiar role of the cruel conqueror; the wounds or spots appear portentous comets; and the altered countenance "Is no deformity, but a disguise. / 'Tis but an Angel's Veil" worn by all who approach the heavenly throne. Shipman could not resist the temptation to lapse into a pattern of familiar conceits perhaps because, like many of the poets in this tradition, he was a second-rank versifier anxious to demonstrate that he too could write whatever currently passed for wit. He and other writers his poem criticizes can be faulted for a lack of imagination and inventiveness all too common in seventeenth-century occasional poetry, but the obvious shortcomings may be symptomatic of a fundamental need to dispel the fearsome. Like Dryden's dubious wit, the conclusion of Shipman's poem strains to transform a truth the poets would rather deny: in the metamorphosis deformity becomes but a disguise and destruction appears fulfilment. Conventional language and gestures are means of coping, and wit functions as an obvious control. The effect, in short, can be seen in the final two poems in this study, James Shirley's 'A Mother hearing her Child was sick of the Small-pox' and Alexander Brome's 'To a Gentleman that fell sick of the small Pox. When he should be married'. Both, in their calculated exaggeration, suggest the often fine line between the intentional and unintentional failure of witty metamorphosis.

Though neither occasion was unusual in the seventeenth century, Shirley's poem responded to the more familiar, even commonplace tragedy. Compared to a nineteenth-century counterpart, Good tidings; or news from the farm, this short, three-stanza poem eschews the sentimental. While the later poem opens with a mother's tearful recollection of the days she spent nursing her child through the blinding disease, ${ }^{97}$ Shirley's poem distances itself from any scene of domestic sorrow as it questions the justice of the suffering. The initial stanzas of familiar, caviling wit play with the beauty now buried in the child's face, appealing to an audience sophisticated enough to appreciate the graceful variation of the topos of divine jealousy. The ultimate effect, however, depends upon the sudden reversal in the last stanza:

But this is still my sorrow, child,

With which turn'd wild,

I send my tears to seek,

And bathe thy wither'd cheek:

Which, could my kisses reach, with warm supplies

I would leave thee no spots, or me no eyes. ${ }^{98}$

By addressing the child directly and stressing an uncontainable, maternal grief, the mother conveys her tender, selfless sorrow. Where wit has failed, tears will now "bathe thy wither'd cheek" and transform the harsh reality. The metaphor of

${ }^{97}$ Robert Bloomfield, Good tidings; or, news from the farm, London, 1804, pp. 14-15.

98 James Shirley, 'A mother hearing her child was sick of the small-pox', in The dramatic works and poems of James Shirley, ed. Alexander Dyce, London, 1833, vol. 6, p. 438. 
ablution is not original, but by playing against and with wit Shirley captures the helplessness and pathos with understated, unsentimental impact that rivals anything in the memoirs and diaries.

Brome's consoling poem, on the other hand, luxuriates in less restrained and more ambiguous wit. Moments of anger and flights of satire combine with tortuous ingenuity and apparent compassion in a deliberately unsettling compendium of smallpox poetry. From the outset the poem plays with language, inviting the unfortunate gentleman to view himself in the lines of the verse. This pun on the physical semblance between the letters on the page and the spots on the face is topped by the atrocious wordplay that ends the description of a countenance adorned "with stars like an enamell'd night":

Your sickness meant to turn Astronomer,

Your face the Heaven, and every spot a Star.

Or else would write an Almanack, and raise,

By those red Letters, nought but holy-dayes. 99

The poem further likens the cursed disease to a treacherous enemy, sports with the reds and whites of Mars and Venus, and concludes with the apology, "Sir if these verses go a halting pace, / They stumble in the vallies of your face." Earlier the poem declares that love goes beyond the physical, but it is obvious Brome could not ignore the disfigurement caused by smallpox. Though the poem flouts the scars, perhaps implying that males should be unconcerned with physical appearance, Brome also took pains to neutralize the change in elaborate comparisons. The extremes are not the confusion of a hack poet who has shuffled a number of incompatible effects in eighty-four lines of verbal exhibitionism. The ironic, playful self-awareness that Brome revealed in his other poetry may well explain the apparent failure of his poetic response to smallpox. Through the surplus of wit Brome deliberately undid his effect; the gentleman invited to seek the solace of wit is faced in the end with a crudely witty reminder of what the poem sought to transform. The failure of wit, in effect, becomes an intentionally ironic, albeit grotesque, comment on the metamorphoses of wit in smallpox poetry.

\section{IV}

Not all of the poems are as calculated as these last two examples, but in their use and abuse of wit many similarly attempt with varying degrees of success to accept the unavoidable. Whether the poems rail against the injustice or jest at the inescapable, they share the need to allay the deep-seated terrors smallpox evoked in the seventeenth century. Attempts to displace and transform the threats none could escape often lead to repetitious imagery and strained comparisons of questionable, even grotesque taste. Though traditions of seventeenth-century poetry and differences in sensibility may account for some of the disconcerting results, the failure

\footnotetext{
${ }^{99}$ Alexander Brome, 'To a gentleman that fell sick of the small pox. When he should be married', in Poems, ed. Roman R. Dubinski, University of Toronto Press, 1982, vol. 1, p. 265.
} 
to please may ultimately reflect a fundamental tension. Many who sought defences against an inexplicable yet commonplace disease, who may have wanted to dismiss it in a quibble or to redefine its appearance, simply did not possess the necessary detachment. A century later, a prize-winning poem entitled 'Beneficial Effects of Inoculation' would sing with new confidence about the epic struggle against smallpox and the heroic triumph of the "country's guardian Montague" and the "heav'n taught nymph", inoculation. ${ }^{100}$ The overwrought lines of this bombastic poem suggest that the advances of medicine guarantee no comparable progress of poetry, but at least in the seventeenth century the physicians' failure to stem the epidemic of smallpox helps to explain the poets' failure to confront the consequences.

${ }^{100}$ William Lipscomb, 'Beneficial effects of inoculation, a prize poem, recited in the Theatre, Oxford in the year MDCCLXXII', in Oxford prize poems, Oxford, 1807. 